\title{
DIREITO, HISTÓRIA E CIÊNCIAS SOCIAIS
}

\author{
LUCIANA HEYMANN, MARCO AURÉlIO VANNUCCHI \\ E PAULO FONTES
}

EDITORES

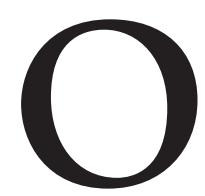

s estudos sobre o campo do Direito consolidaram-se no Brasil nas últimas décadas. Pode-se sugerir que a ampliação do interesse da História e das Ciências Sociais em relação à temática se vincule ao crescente protagonismo do Judiciário na vida pública do país no pós-ditadura militar. 0 vigor dessa área de estudos evidencia-se na existência de simpósios e grupos de trabalhos especializados organizados no interior das principais entidades de História e Ciências Sociais brasileiras.

A produção acadêmica sobre o Direito, com forte traço interdisciplinar, desdobra-se em análises sobre ideias, práticas, instituições e agentes jurídicos. Além disso, proporciona reflexões sobre as fontes documentais e as metodologias utilizadas, e estimula o aprofundamento da reflexão teórica sobre o tema.

Assim, este número de Estudos Históricos pretende exprimir, ainda que parcialmente, a diversidade temática e de perspectivas que distinguem a produção atual sobre o campo do Direito.

0 primeiro artigo, 0 procedimento de manutenção de liberdade no Brasil oitocentista, de Mariana Paes, examina as bases jurídicas da posse da liberdade no quadro da sociedade escravista do século XIX. O segundo artigo, A organização da justiça militar no Brasil: Império e República, de Adriana Barreto e Angela Moreira, oferece um panorama da estruturação e atuação deste ramo da Justiça no período imperial e republicano.

Luciana Heymann, Marco Aurélio Vannucchi e Paulo Fontes são professores da Escola de Ciências Sociais da Fundação Getulio Vargas (CPDOC/FGV). 
Os três artigos seguintes tratam da Primeira República. Em Vadiagem e prisões correcionais em São Paulo, Alessandra Teixeira, Fernando Salla e Maria Gabriela Marinho problematizam o controle e a repressão à vadiagem. Pedro Cantisano, em Direito, propriedade e reformas urbanas, aborda as reformas urbanas realizadas no Rio de Janeiro no início do século XX sob o prisma dos debates jurídicos por elas gerados em torno do direito à propriedade. Já o artigo A atuação do Supremo Tribunal Federal na crise da Política dos Estados na Primeira República, de Leonardo Sato e Priscila Gonçalves, versa sobre o periodismo jurídico, pelo estudo da revista $O$ Direito.

Mariana Silveira, em Direito, ciência do social, articula a participação política dos bacharéis com a produção intelectual que veiculavam em periódicos especializados no primeiro governo Vargas. 0 artigo posterior, 0 sentido democrático e corporativo da não-Constituição de 1937, de Luciano Abreu, analisa a questão da legitimidade da carta constitucional em questão. Ainda no âmbito da Era Vargas, Walter Guandalini Jr. e Adriano Codato, em O Código Administrativo do Estado Novo, refletem sobre a estrutura político-administrativa do regime instaurado em 1937.

O último artigo, Constitucionalismo e batalhas políticas na Argentina, de Fabiano Engelmann e Luciana Rodrigues Penna, investiga as relações entre o constitucionalismo e a política naquele país.

O dossiê Direito, História e Ciências Sociais completa-se com o texto Sobre a história constitucional, de Andrei Koerner. Com ele, Estudos Históricos inaugura a seção Ensaio bibliográfico, destinada a publicar balanços da literatura nacional e estrangeira recente relacionada à temática do número.

Encerram a presente edição da revista os três textos lidos na cerimônia de outorga dos títulos de professoras eméritas da Escola de Ciências Sociais da Fundação Getulio Vargas (FGV/CPDOC) a Angela de Castro Gomes e Lucia Lippi Oliveira. Os títulos foram concedidos pela Congregação do CPDOC, e a cerimônia ocorreu no dia 14 de março deste ano. Em Pioneiras e construtoras, Luciana Heymann destaca a contribuição institucional ao CPDOC das professoras homenageadas pela Congregação. Bernardo Buarque, em Socióloga com olhar histórico ou historiadora com perspectiva sociológica?, percorre a produção intelectual de Lucia, enquanto Paulo Fontes, em Sensei Angela de Castro Gomes, assinala aspectos fundamentais da obra de Angela. 